\title{
Black Slavery in Canada: A structuring Absence in Canada's (Hi)Stories
}

\author{
László Bernáth*
}

\begin{abstract}
In national as well as international terms, Canada holds the image of a savior of African slaves, even though in the recent production The Book of Negroes (CAN/USA 2015) a more critical depiction of Canada is presented. The question, however, remains whether the miniseries, with its admission of discrimination and racism, actually rebuts previously established myths of Canada's relation to slavery. Due to the virtual absence of Canada from the screen when it comes to slave narratives, very little attention has been paid so far to a Canadian perspective in analyzing such artifacts. By looking at the representation of Canada's relationship with black slavery on film and television, I search for patterns and discursive moves which maintain a distance from addressing the country's own slaving past. I apply a critical discourse analytical approach in order to unveil the meanings and cultural implications of information-omission from screen. The overall purpose of my argument is to show that by focusing exclusively on the significantly larger contribution of the United States to the practice, artifacts reinforce the popular notion of Canada's innocence in the enslavement of human beings.
\end{abstract}

Key words: Canada, slavery, film studies

\footnotetext{
* Alpen-Adria-Universität Klagenfurt; 1bernath@edu.uni-klu.ac.at
} 


\section{Introduction}

The trans-Atlantic slave trade and slavery have become popular topics to be dealt with on screen since after the Civil Rights Movement. In a supposedly post-racial society, where race is claimed to matter no more (Bonilla-Silva 2010; Wise 2009; Wise 2010), the remarkable interest in the production as well as consumption of such artifacts seems to indicate that the white population has managed to come to terms with and is now able to face the abominable deeds committed by fellow whites against blacks in the past. However, there is a significant difference between depicting certain events and providing thorough, realistic and sincere information. Besides the still ever-present 'white savior narratives' (Guest Pryal 2012), there is another, much less widely discussed, let alone questioned, level of the 'Canadian savior'. As far as cinematic treatments are concerned, Canada's relation to slavery is almost exclusively represented by fugitive slave narratives, providing safe refuge to slaves fleeing from the United States while remaining in the background all along.

The Book of Negroes (CAN/USA 2015), however, shows a significant improvement in depicting the harsh realities awaiting freed slaves in Canada. In contrast to former productions, Canadian and U.S. American alike, which present the country as a land of opportunity for ex-slaves and their descendants, the miniseries takes a more critical approach concerning the quality of the 'freedom' offered. Yet, despite admitting to racism, discrimination and even racist violence as everyday experiences, The Book of Negroes still fails to question the myth that Africans came to Canada by choice, and reinforces the popular notion of Canada as solely the liberator of black slaves by conveniently placing the practice of slavery itself to the southern side of the border.

In my paper, I attempt to show that The Book of Negroes takes an important step towards deconstructing the myth of Canada as the provider of security and opportunity for fugitive slaves. At the same time, however, such accomplishment by no means indicates that the darker aspect of Canada's relationship with the institution of slavery, its involvement in it, is now addressed either nationally or internationally. In the first chapter, I will analyze the established idealistic representation of Canada in connection to race relations in general and black slavery in particular. In the second chapter, I will use this analysis as a basis on which to compare the achievements and improvements presented by The Book of Negroes with its critical view on Canada and its population. Finally, in the last chapter I will argue that the miniseries is only an initial step - significant as it is - towards addressing a problem rather than the solution to it. The overall purpose of my argument is to show that stories of slavery still fail to discuss Canada's slaving past by focusing exclusively on the significantly larger contribution of the United States to the practice. 


\subsection{Background Section}

Canadian legislation created the dream of freedom within reach for the slaves of the southern neighbor. Following the American Revolution, thousands of Black Loyalists were given the opportunity by the British to settle in what is today Canadian territory and start a new life there as free persons. Yet the most essential acts of legislation came later. On the one hand, the Fugitive Slave Act of 1793 of the United States enabled the seizure of runaway slaves in Northern states, which meant that entering a free state no longer provided security from re-capture. On the other hand, the Act Against Slavery of the same year in Upper Canada made the importation of slaves to the province illegal, that is, it stipulated that every black person was automatically considered free once having entered the province and could not legally be re-enslaved therein (Gallant 2001). Nevertheless, it was not until the passage of a second Fugitive Slave Act in 1850, which obliged every citizen of free U.S. American states to cooperate with the authorities to track down fugitive slaves, that many tens of thousands of black slaves suddenly undertook a virtual exodus to the northern neighbor (Lubet 2010). Many of them escaped through the so-called Underground Railroad, a safety network organized by abolitionists to aid fugitive slaves in the mid- $19^{\text {th }}$ century. Thus, Canada is widely considered a liberator of slaves fleeing from the United States.

However, it is much less widely known, let alone discussed, that Canada had a system of slavery of its own. Marcel Trudel in his groundbreaking work Canada's Forgotten Slaves (1960) unveils French Canada's involvement in the enslavement of Africans as well as First Nations people. The unpopularity of the topic is perfectly symbolized by the fact that besides Trudel's work, which already has a limited scope by only focusing on French Canada, there is hardly any material, let alone book-long treatment, available on the issue. An important aspect mentioned in Trudel's workwith regard to Québec, later Lower Canada, but which was true in every other province as well except for Upper Canada, is that slavery had never been abolished until the general abolition by Britain in its colonies in 1833 (Riddell 1920; Trudel 1960, 250-253; Whitfield 2012; Whitfield and Cahill 2009). However, in contrast to popular perception, even in Upper Canada the aforementioned Act of 1793 did not end slavery. It only outlawed the further importation of slaves, while those already enslaved in the province remained thus until their death, and their children also remained property until they reached the age of 25 (Trudel 1960, 239-240). In fact, the greatest irony is that the Act itself provided a legal basis for the maintenance of slavery in Upper Canada, while in other provinces the outcomes of legal decisions concerning runaway slaves were up to the personal views of the respective justices, which mostly resulted in anti-slavery verdicts in Lower Canada and Nova Scotia (Riddell 1920; Trudel 1960; Whitfield 2012).

The omission and distortion of essential facts such as those mentioned above contributes to the maintenance of popular ignorance about Canadian slavery. Popular culture is a powerful means of spreading - and backgrounding - information, and with it ideologies, among the general population on a large scale (Holtzman 2000; van Dijk 
1988; van Dijk 1991). Therefore, the impact of such artifacts on the popular perception of and ways of thinking about various issues cannot be disregarded. It deserves even more attention and critical analysis if the respective artifact is claimed to be based on true historic events, thereby gaining extra truth-value, or if the topics in question are not likely to be learned about from other, ideally more reliable, sources. As for the issue of slavery in Canada, both cases apply, which means that such depictions have significant influence on the public's knowledge, and can dangerously lead to a situation where, if unquestioned, such ignorance invisibly reproduces itself and is no longer perceived as ignorance at all but as common knowledge (van Dijk 1991; 1993).

\section{The 'Promised Land'}

The Underground Railroad, the most widely known safety network organized by abolitionists to aid fugitive slaves, has become the representative of Canada's relation to slavery nationally as well as internationally. If, as Odgen, Perkins, and Donahue observe, "England, if considered at all, is seen as a champion of the anti-slavery movement, having abolished slavery earlier in the nineteenth century" $(2008,469)$, then Canadians can boast with an even more positive representation or, more often, with the convenience of non-representation and thus the apparent lack of involvement in the issue. Cinematic treatments of slavery that do refer to Canada deal, virtually without exception, with fugitive narratives in general and the Underground Railroad in particular. Productions such as the Canadian made-for-television film Race to Freedom: The Underground Railroad (CAN 1994), the story of black slaves escaping from southern plantations and, in crests and troughs, finally crossing the Canadian border to gain their liberty, are the prototypical dramatic treatments of slave narratives featuring Canada. Thus, Canada's presence in such movies is little more than an abstract idea in the minds of slaves which stands for their ultimate goal: freedom.

Canadians' apparent humanitarianism, however, is shown to have made more substantial contributions to the escape of fugitives than only the eventual, and rather passive, legal liberation. The general theme of the Underground Railroad in film involves predominantly white abolitionists who help slaves along their way, that is, act as indispensable saviors that slaves must rely on in order to succeed. In the majority of cases, the 'good guy' vs. 'bad guy' dichotomy is drawn between the profoundly simplified images of the anti-slavery Northern and the pro-slavery Southern U.S. American (Ogden, Perkins, and Donahue 2008). Yet sometimes representatives of other nations, rarely more than one individual, whose actions, as a rule, are indicated to be representative of their home country's attitude at large, appear in film (ibid.). With regard to Canadians, there are not many appearances to be analyzed to begin with, but even in those few instances the diversity in the characters' role in the story is negligible. If Canadians appear at all, they play ardent abolitionists - such as the savior Dr. Alexander Ross (Michael 
Riley) in Race to Freedom, who, symbolically, happens to be an ornithologist, or Samuel Bass (Brad Pitt) in 12 Years a Slave (UK/USA 2013) - who sacrifice their own safety, even potentially their lives, for the sake of the slaves' liberty. When Bass in 12 Years a Slave explains his anti-slavery stand to Solomon Northup (Chiwetel Ejiofor), the impression is that his Canadianness is in itself the explanation as to why he condemns the enslavement of other human beings. He only questions the morality of the U.S. Constitution, for instance, in a rather unemotional tone as if delivering a dry legal argument, which presents him not so much as a passionate activist rather than a representative of the average Canadian. In general, nowhere is there a Canadian person shown who is not an abolitionist but is indifferent about slavery or even supports it (Small 2014). The absence of such counterbalance clearly implies that, by and large, anti-slavery views and abolitionist involvement were absolutely self-evident in Canada and to Canadians (ibid.).

From a slave or later Black Canadian point of view, the treatment of the Underground Railroad or fugitive stories in isolation from a transnational picture is inherently problematic, as the topic is almost exclusively approached from a white U.S. American perspective. Even in Race to Freedom, where the abolitionist white hero is Canadian, the point of view of the storytelling remains white in general and U.S. American in particular. What Canada means in the films, the liberator, is defined by the U.S. American perception of it based on knowledge of nothing more than a legal document abolishing slavery, which is then reflected in the similarly white-determined purpose of slaves. The concept of 'freedom' presented in the movies is only understood in legal terms, which is then implemented in the ways of thinking of escaped slave characters as well. Thus, even black characters are constructed by filmmakers to operate within a white perspectivist framework (van Dijk 1993), as if black slaves and whites had had the same experiences and could have the same, rather limited, concerns for a future in Canada. The ultimate failure of fugitive narratives which omit a Canadian perspective is that they unanimously avoid questions of permanence and thus of the quality of the celebrated freedom, disregarding that "sameness and equality are very different phenomena." (Holtzman 2000, 22) By means of absolute and happy closure at the moment of crossing the border, it is implied that blacks no longer faced barriers to thriving in their new homeland. Hence, an analysis of the fate of fugitives is inevitably incomplete without touching on Canada and what it had to offer to them following legal liberation. In order to create a more complete picture of what the Underground Railroad and Canada truly meant to blacks themselves - after all, they were the ones who actually experienced the way and then the place it led them to, it is also indispensable to develop a simultaneous, all-encompassing combination of black and trans-border perspectives.

Cinematic attempts to tell specifically Canadian stories beyond the fugitive narrative are remarkably scarce. The only artifact of similar intention that has received at least some attention is the Canadian-U.S. American co-production Captive Heart: The James Mink Story (CAN/USA 1996). The main character, James Mink, played by the 
acclaimed actor Louis Gossett Jr., is the son of a former slave, and now a successful businessman; in fact, he is among the richest people in mid-nineteenth century Toronto. While the rest of the story is not directly relevant to this argument, the fact that an immediate descendant of a slave became a millionaire and celebrated political figure in Canada again implies for the viewer that Canada was a true land of opportunity for liberated slaves and their descendants.

This remarkably positive impression is achieved by the use of several discursive strategies that help create a tilted picture without necessarily telling lies, even though, in this case, the creators of Captive Heart did have an extremely loose understanding concerning the requirements of historical accuracy to allow themselves to claim the film to be 'based on a true story' (Fisher 2016). The most fundamental move applied is what Tim Wise, in the context of race, calls 'enlightened exceptionalism' (Wise 2009), which means that an exceptional, individual case or event is chosen and presented so as to appear to be representative of a much larger picture (ibid., 28-29; Guest Pryal 2012). In this instance, James Mink's success story was clearly an exception to the rule that Black Canadians, by and large, had to live in very poor conditions (Small 2014). The second, and no less relevant, strategy consists of backgrounding and/or exclusion. Captive Heart further reinforces the notion of Canadian society's colorblindness by showing Mink's popular respect by making him run for the position of Mayor of Toronto, which, in fact, he never did (Fisher 2016), and his power and control over the white population by turning down the offers of numerous 'unworthy' whites who intend to marry his daughter. Although the false implications cannot be considered lies, the film certainly does not even remotely present a sincere picture of race relations in Canada at the time. Information that would undermine the intended message of having opportunity for all regardless of race, such as the not-so-irrelevant fact that, in reality, Mink's estate was set on fire by racists, whereby he lost everything and eventually died in poverty, is conveniently omitted so as not to contaminate the positive depiction of Canada as a land of equality and opportunity.

\section{The Land of Loss}

In comparison to the previous examples, The Book of Negroes (CAN/USA 2015) provides a radically different image of Canada. The miniseries corrects the two major shortcomings of previous treatments: On the one hand, unlike fugitive slave narratives, it features Canada itself as a location of action, and, as opposed to Captive Heart, it focuses on the life and struggles of a larger, average community rather than on the exceptional story of a single individual. After the transport of about three thousand Black Loyalists to Canada in 1783, the majority to Nova Scotia, the episodes set there depict the various difficulties of living on the still barren land. 
The arrival in Canada is no longer shown to mean survival per se but simply the continuation of the struggle to survive in a different place and context. The essential deviation from the established norm of referring to Canada as a 'paradise' for former slaves and their descendants is made quite clear long before the Black Loyalists set foot in Nova Scotia. When Captain John Clarkson (Ben Chaplin) first mentions the British intent of transporting blacks to the colony of Nova Scotia, he immediately tells Aminata (Aunjanue Ellis) that even though blacks will be "entirely" free there (Episode 4, 6:04), "there will be hard work." (ibid., 6:10) The actual conditions, however, turn out to be much more problematic than just having to work hard. Aminata's apt description to Chekura (Lyriq Bent) sums up what the 'promised land' has to offer: "Moose, wolves, bear, every manner of massive wildlife, but you can barely grow a potato or a carrot or an onion; even chickens freeze." (Episode 5, 32:42) It is a place to die in, where disease devastates the population, including Aminata's newborn, and where people are forced to steal in order to survive, only to be hanged afterwards for having stolen. In the Canada of the miniseries, death is so much omnipresent that the sight of a crushed, dead body with wolves feeding on it no longer evokes any reaction in inhabitants because they have become accustomed to these sights on a daily basis. The initial images on the way from the port to Birchtown, the black settlement, already establish that perhaps the only difference between freedom in Nova Scotia and enslavement in the South of the United States is that while in the latter blacks toil in unbearable heat, in the former they do much the same in the freezing cold.

The major achievement of The Book of Negroes is that, unlike previous success stories, it depicts white Canadian society as deeply racist. Literally in her very first seconds on Canadian soil, Aminata already encounters hatred as a black person when being 'welcomed' by white men throwing peanuts at her. As the story-line develops, it becomes clear that racism is indeed a taken-for-granted phenomenon that is pervasive in every aspect of life, confirming historical records that people of African descent "were regularly reminded that they belonged on the lowest level of society, or indeed outside of society altogether." (Whitfield 2012, 27) A black person is paid half of what whites earn with the same work, and some, such as Cummings Shakspear (Stephan James), even decide to indenture themselves in order not to starve, thus, in effect, returning to slavery for a limited period of time. Even so, however, blacks are attacked for supposedly taking away jobs and opportunities from whites. The all-encompassing prejudice towards blacks reaches its climax when Mrs. Witherspoon (Jane Alexander), Aminata's employer, vows revenge on the black population at large for the murder of her son Matthew (Joel Thomas Hynes). Although neither she nor the authorities know who committed the crime, it is considered self-evident that only a black person could or would do so. When the tensions develop into racist riots and Birchtown is burned down and several blacks are murdered or lynched, it becomes clear that people of African descent have no stay in Canada. What is important to note in addition is that, while in the miniseries the riots break out nine years after arrival, in reality the Shelburne Riots, on which the 
depiction is based, happened little more than half a year after the Black Loyalists settled in the colony (Robertson 2014). Nevertheless, the miniseries provides a realistic picture of how the majority of whites "rejected anything resembling equality with their black neighbors" (Whitfield 2012, 43), and "opted for a system of social subordination and absolute economic control.” (ibid., 44) Race relations in Canada are perfectly symbolized by the manner in which the Canadian part of the story ends: Blacks are relocated to Freetown, Sierra Leone. Thus, it is admitted that racism is so pervasive in Canadian society that any attempt to maintain order between black and white communities is inherently futile. The only option left is therefore to deport Africans out of the colony.

An important message that The Book of Negroes conveys is that humanitarianism was not the driving force for liberating Africans. Although Captain Clarkson, who represents British abolitionists, shows deep sympathy towards and concern about blacks, freed slaves are little more than tools to be used by the British for their own purposes. Black Loyalists are always assigned tasks that serve the interests of the Crown. Both in Nova Scotia and later in Sierra Leone, they are needed as cheap labor to build up civilization in the respective colonies out of wilderness. Those who do not accept the conditions are left out in the cold despite having served the British in the Revolutionary War. Thus, after the Shelburne Riots, those who do not wish to be relocated and start building up their lives from zero all over again remain abandoned in a profoundly racist community without any meaningful action taken to improve the conditions and resolve the racial tension. Black Loyalists are shown to matter only as long as their labor and capabilities can be exploited with the least possible expenditure, while they are forsaken when in need. Therefore, without denying the significance of progressive values and thinking in freeing Loyalist slaves, the miniseries raises the question as to whether concern for former U.S. American slaves would have been the same had the British and their colonies not been able to draw direct profit from their labor.

\section{The Land of Denial}

Despite its emphatic depiction of the racist environment on Canadian soil, The Book of Negroes does not actually refute the idealistic images of previous artifacts. As far as Canada is concerned, the miniseries is unique in its being set at the end of the $18^{\text {th }}$ century. It shows the conditions in Nova Scotia immediately following the Revolutionary War, that is, during the nine-year period between 1783 and 1792. In contrast, all the other treatments featuring Canada, one way or another, are set in the mid-19th century. While this can be considered inevitable with regard to stories of the Underground Railroad, since it was the period when the safety network was, by far, at its busiest (Lubet 2010; Soike 2013), it is an interesting and relevant coincidence that both Captive Heart and 12 Years a Slave are based on narratives from exactly the same time. Thus, these stories combined provide a remarkably strong foundation to the notion that Canada was 
indeed the land of black liberty and racial acceptance in the 1840s and 1850s. In relation to these images, the critical approach of The Book of Negroes is of little value since the miniseries tackles an entirely different historical period. The temporal distance along with the lack of variety in the qualitative depiction of either era allow for a clear-cut dichotomy of 'the bad late- $18^{\text {th }}$ ' and 'the good mid- $19^{\text {th }}$ ' centuries. Therefore, based on cinematic representations, one can easily arrive at the false conclusion that, by the 1850s, Canadians had successfully eliminated racial oppression, which had been so prominent and all-encompassing only 60 years before. Such a notion of improvement can easily be disproved by reading the following excerpt from Halifax's Morning Post from November $8^{\text {th }}, 1842$ : "The free negro population of this province, pressing, for the most part, like a dead weight on the community, might have given England an argument [against abolition] that it would have been impossible to repel - of the national slothfulness of the African disposition." (Quoted in Whitfield 2012, 44) At first look, The Book of Negroes may seem to create a counter-argument to those positive images, yet, in fact, it simply does not operate in the same context and thus cannot be considered a rebuttal of previously established myths.

In fact, The Book of Negroes continues to reinforce the notion of Canada's innocence when it comes to involvement in slavery itself. The miniseries tells the story which, despite the lack of popular cultural attention, "is so familiar to Maritime historians that it hardly needs to be retold" and "the literature about [it] is voluminous." (Whitfield and Cahill 2009, 34) Such interest in black history in the region, and in Canada as a whole, comes to a virtual full stop, however, when Canadian slavery is in question. The Book of Negroes is exceptional in its indication, implicit as it is, of an existing slaving system on Canadian soil. Yet, even there, the only reference to domestic slavery is when Daddy Moses (Louis Gossett, Jr.) tells Captain Clarkson that "we have slave owners and slave property, and desperate people indenturing themselves into servitude." (Episode 5, 27:39) Clarkson's reply that "I regret profoundly the disappointments that have shaken you so. And that's why I've come" (ibid., 27:46) is contradicted by his own statement a few seconds later, when he explains that "you can't join us on this grand adventure [to Sierra Leone] if you are enslaved, indebted, or indentured.” (ibid., 28:33) Essentially, those who would need help the most are the ones left out in the cold. Even more importantly, however, Clarkson's regret seems to imply that slavery has been unknown to and unanticipated by the British, and thus a marginal, underground activity at best. Its existence is no longer denied entirely, but its relevance is still mitigated and it still remains an off-screen 'side-note' rather than a narrative in and of itself (Whitfield 2012, 18). In general, The Book of Negroes confirms Whitfield and Cahill's observation that "[s]lavery is not seen as an integral part of this region's history, but rather as an alien and exceptional practice imported from the United States." (2009, 31)

Nevertheless, the miniseries is only one component to a much broader, systematic problem. The treatment of the issue of slavery in a specifically Canadian context is yet to gain popular attention and interest. In no cinematic depiction of slavery I have been 
able to access is Canada presented as a slaveholding nation. Although The Book of Negroes makes reference to the existence of the practice, Canadian slave narratives never appear on screen. Such absence gives an impression similar to that of Captain Clarkson's regretful speech: that slavery in Canada was not a prevalent issue. To paraphrase and adopt Linda Holtzman's remark on the absence of disabled people from screen, if there are no images of Canadian slavery in the films we see, the one message which is conveyed with certainty is that Canada's slaving past, if acknowledged at all, is not relevant enough in history to see or hear about it $(2000,47)$. In this sense, missing presence means empowerment. The singularity of a few cinematic treatments featuring Canada bestows them with extraordinary influence on the views of the public (ibid., 41). An excellent, and eye-opening, example for such a phenomenon is Captive Heart, which is, in fact, not based on a true story but on a popular legend whose only resemblance to reality is that a black businessman called James Mink indeed existed (Fisher 2016). Nevertheless, if one searches for information on the protagonist and his life, one finds historical truth-claims to either the entire plot of the movie or at least to some vital parts of it. The power of such images, thus, lies in their thematic uniqueness because no divergent voices and perspectives are present to potentially debunk the established myths. In such cases, however, there is at least the opportunity to use the information available to question them and thus possibly come up with a counter-argument. In the case of absences, on the other hand, "[i]f vast areas of information are simply not [present], many facts cannot even be used to build counterinformation and hence counterideology." (van Dijk, 1988, 202). By replicating a positive or simply disconnected image of Canada in relation to slavery without giving voice to alternative narratives, the dominant ideology of Canadian innocence can easily be maintained as well as reinforced, and can be made unquestionable 'common knowledge' to the public without apparent ideologically charged content (Holtzman 2000, 34-35; van Dijk 1991, 37).

\section{Conclusion}

The issue of slavery has yet to be adopted into the Canadian national narrative. North American slavery offers itself to a U.S. American focus both because of the profound contribution of the United States to the enslavement of Africans and because of its dominance over information flow and the media in general. Nevertheless, slavery needs to be acknowledged and discussed as a part of specifically Canadian history as well. The institution has to be re-contextualized into a Canadian framework rather than simply compared to the United States in purely statistical terms. Numbers can be deceptive: In the same period when the Thirteen Colonies, or later the United States, were wellestablished, Canada was either in the initial phase of being built or entirely unsettled by Europeans. In this respect, while Canada's contribution to black enslavement does not appear significant internationally, slaves nevertheless made a profound contribution 
to the establishment of the colony (Johnston 1978; Riddell 1920). Therefore, in order to provide a comprehensive picture of Canadian slavery, it is necessary to take into consideration the significantly different conditions in Canada in comparison to other major slave-holding nations and introduce a micro-level perspective of the institution as well.

Besides the adoption of a specifically Canadian perspective on the analysis of slavery in North America, it is essential to present the issue from an insider's perspective. Stories featuring minority narratives in general are almost exclusively told from the point of view of the dominant majority. As Haile Gerima, an acclaimed independent filmmaker from Ethiopia, tells in an interview, the first question a filmmaker planning to tackle minorities on screen receives is "Who is the white lead person that the Blacks will be endorsed by for a commercial guarantee?” (Gerima and Woolford 1994, 102) Thus, they are stories about rather than stories by those concerned. The most fundamental step towards realistic, thorough and inclusive depictions of minorities and their histories would be to allow them to tell their own stories for and about themselves, without being concerned about having to satisfy the predominantly white audience. Only an insider can experience, see and feel all the barriers to be broken and gaps to be bridged over, which would otherwise be invisible from the perspective of the dominant and the privileged.

\section{References}

\section{Primary Sources}

Braithwaite, Diana, Peter Mohan, and Nancy Trites-Botkin. Race to Freedom: The Underground Railroad. Directed by Don McBrearty. Santa Monica, California: Xenon Entertainment Group, 1994.

Ridley, John. 12 Years a Slave. Directed by Steve McQueen. Los Angeles, California: Fox Searchlight Pictures, 2013.

Virgo, Clement, and Lawrence Hill. The Book of Negroes. Directed by Clement Virgo. Toronto: Entertainment One Television, 2015.

White, Bryon, Brian Bird, and John Wierick. Captive Heart: The James Mink Story. Directed by Bruce Pittman. New York: Columbia Broadcasting System, 1996.

\section{Secondary Sources}

Bonilla-Silva, Eduardo. 2010. Racism without Racists. Lanham, Maryland: Rowman and Littlefield Publishers, Inc.

Fisher, Jack. "ACO sponsors speaker for Black History Month.” Ontarion (Guelph, Ontario), Feb. 24, 2016. http://www.theontarion.com/2016/02/aco-sponsors-speaker-for-black-historymonth-2

Gallant, Sigrid Nicole. 2001. "Perspectives on the Motives for the Migration of African-Americans to and from Ontario, Canada." The Journal of Negro History 86 (3): 391-408. 
Gerima, Haile, and Pamela Woolford. 1994. “Filming Slavery.” Transition 64: 90-104.

Guest Pryal, Katie Rose. 2012. "Hollywood's White Legal Heroes and the Legacy of Slave Codes." In Afterimages of Slavery, edited by Marlene D. Allen and Seretha D. Williams, 145-163. Jefferson, North Carolina: McFarland and Company, Inc., Publishers.

Holtzman, Linda. 2000. Media Messages. Armonk, New York: M.E. Sharp, Inc.

Johnston, T. 1978. “The Canadian Black Population and Immigration.” Anthropos 73 (3/4): 588-592.

Lubet, Steven. 2010. Fugitive Justice. Cambridge, Massachusetts: Harvard University Press.

Ogden, Nancy, Catherine Perkins, and David M. Donahue. 2008. "Not a Peculiar Institution." The History Teacher 41 (4): 469-488.

Riddell, William Renwick. 1920. "Slavery in the Maritime Provinces." The Journal of Negro History 5 (3): 359-375.

Robertson, Jesse. “The Shelburne Race Riots.” Canadian Encyclopedia (Toronto), Nov. 19, 2014. http://www.thecanadianencyclopedia.ca/en/article/the-shelburne-race-riots/

Small, Takara. “Canada's secret slave-owning past revealed.” Metro (Toronto), Feb. 10, 2014. http://www.metronews.ca/news/canada/2014/02/10/canadian-secret-slave-past.html

Soike, Lowell. 2013. Necessary Courage: Iowa's Underground Railroad in the Struggle against Slavery. Iowa City, Iowa: University of Iowa Press.

Trudel, Marcel. 1960. Canada's Forgotten Slaves. Translated by George Tombs (2013). Montréal: Véhicule Press.

Van Dijk, Teun Adrianus. 1988. News Analysis. Hillsdale, New Jersey: Lawrence Erlbaum Associates, Publishers.

Van Dijk, Teun Adrianus. 1991. Racism and the Press. London: Routledge.

Van Dijk, Teun Adrianus. 1993. Elite Discourse and Racism. Newbury, California: SAGE Publications, Inc.

Whitfield, Harvey Amani. 2012. “The Struggle over Slavery in the Maritime Colonies.” Acadiensis 41 (2): 17-44.

Whitfield, Harvey Amani, and Barry Cahill. 2009. "Slave Life and Slave Law and Colonial Prince Edward Island, 1769-1825.” Acadiensis 38 (2): 29-51.

Wise, Tim. 2009. Between Barack and a Hard Place. San Francisco, California: City Lights Books. Wise, Tim. 2010. Colorblind. San Francisco, California: City Lights Books.

Zellars, Rachel. "Canada's long history of racism.” Montreal Gazette, Aug. 18, 2015. http://montre algazette.com/news/quebec/opinion-canadas-long-history-of-anti-black-racism. 